\title{
HOTS-Based Learning Model
}

\author{
Fifit Firmadani ${ }^{1}$, Atsani Wulansari ${ }^{2}$ \\ \{firmadani@untidar.ac.id¹, atsani_wulansari@untidar.ac.id² \\ ${ }^{1,2}$ Universitas Tidar, Indonesia
}

\begin{abstract}
Learning as an activity in education should have a real contribution to students. Recently, global competition requires quality learning and requires students that can solve a problem. High Order Thinking Skills (HOTS) is the ability to connect, manipulate, and change the knowledge and experience owned critically and creatively in determining decisions to resolve problems in new situations. Several learning models can be said to be based on high Order Thinking Skills (HOTS) i.e. discover / inquiry learning, problem-based learning, and project-based learning, the three learning models can be applied at all levels of education. The teacher's role in HOTS-based learning is only as a facilitator and stimulates questions that encourage students' original thoughts to emerge.
\end{abstract}

Keywords: Learning, HOTS.

\section{INTRODUCTION}

Education plays an important role in educating the next generation of the nation. Through education, a nation will have a character and have strong competitiveness from other nations. Education will also shape the act of future generation. Education is a very important weapon to prepare reliable Human Resources, while teachers are the spearhead of education.

The essence of education as an educational activity or teaching and learning activities lies in learning, and the essence of learning lies in thinking [1]. Education is an effort to teach students to think. Learners must emphasize thinking skills. Learners must be directed so that they can think critically, think highly and independently in learning activities. Thinking skills can be divided into two levels; higher-order thinking skills (HOTS) and lower-level thinking skills (LOTS).

Higher-Order Thinking Skills (HOTS) are needed in the current era of globalization. The teachers no longer teach the students to know but to find out for themselves. Finding out means requiring an intelligent and creative thought process. High order thinking skill requires students to remember, understand, even to solve the complex problems. Complex thinking skills will make students accustomed to facing something difficult. In facing those difficulties requires high-level thinking skills. Therefore, in learning there is a need for a HOTS-based learning model that makes students not only accept material but also be problem solvers.

\section{METHOD}

This research is a qualitative research using secondary data analysis. Qualitative research means compiling the results of research analysis using descriptive form of words. Secondary analysis is a systematic method with procedural and evaluative steps The process os secondary 
data analysis are the development of the research questions, the identification of the dataset, and the evaluation the dataset [2]. Furthermore, The researchers collected data from several libraries related to the HOTS-based learning model.

\section{RESULT AND DISCUSSION}

HOTS-based learning models are as follows:

\section{a. Discover/inquiry learning}

The discovery/inquiry learning model is understanding concepts, meanings and relationships through an intuitive process to finally conclude. Discovery occurs when individuals involved primarily in the use of mental processes find several concepts and principles. Discovery is done through observation, classification, measurement, prediction, determination, and inference. The steps of the discovery learning model are as follows:

A. Syntax of Discovery Learning model:
a. Providing stimulation
b. Problem statement/identification
c. Data Collection
d. Data Processing
e. Verification
f. Drawing conclusions / generalization

Table 1. the steps of discovery learning that can be designed by the teacher

\begin{tabular}{lll} 
Work Steps & Teacher's Activity & Students Activity \\
\hline
\end{tabular}

Providing stimulation

The teacher starts the learning
activities by asking questions,
encouraging reading books, and
other learning activities that lead to
the preparation of problem-
solving

The teacher starts the learning encouraging reading books, and the preparation of problem- -participants are faced with a case that confuses, then proceed not to provide generalizations, so that the desire to investigate itself arises.

- stimulation in this phase serves to provide conditions for learning interactions that can develop and assist students in exploring material.
Problem statement / identification
The teacher allows students to identify as many problem agenda as possible that are relevant to the subject matter, then choose one of
The selected problem must then be formulated in the form of questions or 


\begin{tabular}{|c|c|c|}
\hline & $\begin{array}{l}\text { them and formulate it in the form of } \\
\text { a hypothesis }\end{array}$ & $\begin{array}{l}\text { hypotheses, statements } \\
\text { as temporary answers } \\
\text { to the questions raised }\end{array}$ \\
\hline Data Processing & $\begin{array}{l}\text { The teacher provides guidance } \\
\text { when students do data processing }\end{array}$ & $\begin{array}{l}\text { Data processing is an } \\
\text { activity to process data } \\
\text { and information } \\
\text { through interviews, } \\
\text { observations, etc., then } \\
\text { interpreted. All } \\
\text { information from } \\
\text { reading, interviewing, } \\
\text { observing, etc., are } \\
\text { processed, } \\
\text { randomized, classified, } \\
\text { tabulated, and if } \\
\text { necessary, the } \\
\text { information } \\
\text { calculated in a certain } \\
\text { way and interpreted at } \\
\text { a certain level of } \\
\text { trust. }\end{array}$ \\
\hline Verification & $\begin{array}{l}\text { Verification aims to create a } \\
\text { creative and good learning process. } \\
\text { Here, the teacher allows students to } \\
\text { find a concept, theory, rules or } \\
\text { understanding through the examples } \\
\text { they encountered in their life. }\end{array}$ & $\begin{array}{l}\text { Students carry out a } \\
\text { careful examination to } \\
\text { prove whether or not } \\
\text { the hypothesis } \\
\text { specified earlier with } \\
\text { alternative findings, } \\
\text { connected with the } \\
\text { results of data } \\
\text { processing }\end{array}$ \\
\hline $\begin{array}{l}\text { Drawing conclusions / } \\
\text { generalization }\end{array}$ & $\begin{array}{l}\text { Drawing conclusions is the process } \\
\text { of concluding that can be used as a } \\
\text { general principle and applies to all } \\
\text { the same events or problems, taking } \\
\text { into account the results of } \\
\text { verification }\end{array}$ & $\begin{array}{l}\text { Based on the results of } \\
\text { the verification, the } \\
\text { principles underlying } \\
\text { the generalization are } \\
\text { formulated }\end{array}$ \\
\hline
\end{tabular}

B. Syntax of Guided Learning Inquiry model

Learning models are designed to bring students into the research process through investigation and explanation in a short time setting [3]. The inquiry learning model is a learning activity that maximally involves all the abilities of students to search for and investigate something systematically critical and logical so that they can formulate their findings.

The syntax/stage of the inquiry model includes: 

a. Problem orientation
b. Data collection and verification
c. Data collection through experiments
d. Organizing and formulating explanations
e. Analysis of the inquiry process

\section{b. Problem-based learning}

The problem-based learning model is learning that uses a variety of thinking skills of individual students or groups as well as the real environment to overcome problems so that they are meaningful, relevant, and contextual [4]. The purpose of problem-based learning (PBL) is to improve the ability to apply concepts to new or real problems, to integrate the concept of Higher Order Thinking Skills (HOTS), to increase the desire of learning, to direct self-learning and skills.

The characteristics in PBL according to Tan [5] are: (1) the problem is used as a beginning of learning, (2) the problem used is usually a real-world problem that is presented in illstructured, (3) the problem usually requires multiple perspectives, (4) the problems make learners challenged to get new learning, (5) strongly prioritizes independent learning, (6) utilizes varied sources of knowledge, not from one source, and (7) collaborative, communicative and cooperative learning. These characteristics demand students to be able to use higher-order thinking skills, especially problem-solving skills.

In PBL the teacher acts as a guide on the side rather than a sage on the stage. This emphasizes the importance of learning assistance in the early stages of learning. Learners identify what they know and don't know based on the information from textbooks or other sources of information.

The syntax of the PBL model according to Arends [6] are as follows:
a. Learner orientation to the problem
b. Organize students to learn
c. Guide individual and group investigations
d. Develop and present the work
e. Analyze and evaluate the problem-solving process 
Table 2. the steps of problem-based learning that teachers can design

Work Steps Teachers Activity Students Activity

Learner orientation to the problem
The teacher presents the problems that will be solved in a group. Issues raised should be contextual. Problems can be discovered by students through reading material or activity sheets
Organize students to learn
The teacher makes sure each member understands their assignments.
The group observes and understands problems raised by the teacher or obtained from the suggested reading material.
Learners discuss and share tasks to find data/materials/tools needed to solve problems.

Guide individual
and group
investigations

investigations
The teacher monitors the involvement of students in collecting data/materials during the investigation process.
Learners conduct an investigation (looking for data/references/sources) for group discussion material
Develop and
present the work evaluate the problem-solving process
The teacher monitors the discussion and guides the preparation of the report so that the work of each group is ready to be presented
The group conducts discussions to produce solutions of problem-solving and the results are presented in the form of work

\begin{tabular}{ll}
\hline & The teacher guides the \\
Analyze and & presentation and \\
evaluate the & $\begin{array}{l}\text { encourages the group to } \\
\text { problem-solving } \\
\text { process }\end{array}$ \\
& $\begin{array}{l}\text { input appreciation and } \\
\text { inper groups. }\end{array}$
\end{tabular}

The advantages of this model according to Akinoglu \& Tandogan [7] are:

a. Students-centered learning 
b. Develop students' self-control

c. Enabling students to learn about events in a multidimensional and in-depth manner

d. Developing problem-solving skills

e. Encourage students to learn new material and concepts when solving the problems.

f. Develop social skills and communication skills that enable them to learn and work in teams.

g. Develop high-level/critical scientific thinking skills.

h. Integrating theory and practice that allows students to combine old knowledge with new knowledge.

i. Motivate learning.

j. Students acquire skills to manage time.

k. Learning helps the students' way of learning throughout life.

\section{c. Project-based learning}

The project-based learning model is a learning model that involves the activeness of students in solving the problem. It is carried out in groups / independently through scientific stages with a specific time limit outlined in a product to be presented to others.

Project-based learning characteristics are:

a. The completion of tasks is done independently from the planning, preparation, and product exposure.

b. Learners take full responsibility for the projects that will be produced.

c. Projects involve the role of peers, teachers, parents, and even the community.

d. The class situation is very tolerant of the lack and development of ideas.

Table 3. The steps of Project-Based Learning

Work Steps Teachers Activity Students Activity

Fundamental

Questions

product planning
The teacher presents the topic and asks questions on how to solve the problem
Asking fundamental questions of what students should do about the topic/problem solving

\begin{tabular}{lll}
\hline $\begin{array}{l}\text { Designing product } \\
\text { planning }\end{array}$ & $\begin{array}{l}\text { The teacher ensures that } \\
\text { each student in the group } \\
\text { chooses and knows the } \\
\text { procedures for making } \\
\text { the project/product that } \\
\text { will be produced }\end{array}$ & $\begin{array}{l}\text { Learners develop plans of the } \\
\text { problem-solving } \\
\text { including the division of tasks, } \\
\text { preparation of tools, materials, } \\
\text { media, resources needed. }\end{array}$ \\
$\begin{array}{l}\text { Monitoring the } \\
\text { activity } \\
\text { progress of the } \\
\text { project }\end{array}$ & $\begin{array}{l}\text { The teacher monitors the } \\
\text { activeness of the students } \\
\text { while implementing the } \\
\text { project, monitors the } \\
\text { realization }\end{array}$ & $\begin{array}{l}\text { Learners make the project } \\
\text { according to schedule, record } \\
\text { each stage, discuss problems } \\
\text { that arise during project }\end{array}$ \\
\hline
\end{tabular}


developments and guides

if the students experience

completion with the teacher

difficulties

\begin{tabular}{|c|c|c|}
\hline Test Results & $\begin{array}{l}\text { The teacher discusses the } \\
\text { project prototype, } \\
\text { monitors student } \\
\text { involvement, measures } \\
\text { the achievement of } \\
\text { standards }\end{array}$ & $\begin{array}{l}\text { Discusses the feasibility of } \\
\text { projects that have been made } \\
\text { and reports on products/works } \\
\text { to be presented to others }\end{array}$ \\
\hline $\begin{array}{l}\text { Evaluation } \\
\text { Learning } \\
\text { Experiences }\end{array}$ & $\begin{array}{l}\text { The teacher guides the } \\
\text { project presentation } \\
\text { process, response to the } \\
\text { results, then the teacher } \\
\text { and students } \\
\text { reflect/conclude }\end{array}$ & $\begin{array}{l}\text { Each student presents the report, } \\
\text { the other students give their } \\
\text { responses, and together with the } \\
\text { teacher concludes the results of } \\
\text { the project. }\end{array}$ \\
\hline
\end{tabular}

The application of project-based learning is as follows:

a. Topics/materials studied by students are contextual and easily designed into an interesting project/work.

b. Students are not led to producing just one project, (one student produces one project).

c. Projects do not have to be completed in one meeting (completed in three-four meetings)

d. A project is a form of problem-solving so the project improves learning outcomes.

e. Materials, tools, and media needed to make the project should be available in the surrounding environment and are directed to recycle the trash.

f. An authentic assessment emphasizes the ability to design, implement, find and convey its products to others.

\section{Conclusion}

HOTS-based learning is very important in the current era of globalization. Students not only receive material from teachers but also require to be a problem solver. There are three HOTS based learning models called Discovery learning, Problem Based Learning, and Project-Based Learning. All of them are learning models that can train students' critical thinking skills with teaching facilitators. The learning model can be implemented in certain situations and conditions by paying attention to the material taught, student characteristics, and the time needed for the learning process.

\section{REFERENCES}

[1] A. Sanusi, Pendidikan untuk Kearifan. Bandung: Nuansa Cendekia, 2016.

[2] M. P. Johnston, "Secondary Data Analysis: A Method of which the Time Has Come," Qual. Quant. Methods Libr., vol. 3, pp. 619-626, 2014, doi: 10.1159/000479695. 
[3] B. R. Joyce, M. Weil, and E. Calhoun, Models of teaching. Boston: Allyn and Bacon, 2000.

[4] O.-S. Tan, Problem-based Learning Innovation: Using problems to power learning in the 21 st century. Singapore: Cengage Learning, 2003.

[5] M. T. Amir; "Inovasi Pendidikan Melalui Problem Based Learning: Bagaimana pendidikan memberdayakan pemelajar di era pengetahuan," 2010.

[6] R. Arends, Learning to teach. McGraw-Hill, 2012.

[7] O. Akinoğlu and R. Ö. Tandoğan, "The effects of problem-based active learning in science education on students' academic achievement, attitude and concept learning," Eurasia J. Math. Sci. Technol. Educ., vol. 3, no. 1, pp. 71-81, 2007, doi: 10.12973/ejmste/75375. 